\title{
First Travel Narrative in Telugu: A Study of Yenugula Veeraswamaiyya's Kasi Yatra Charitra
}

\author{
M. G. Prasuna \\ Associate Professor, Department of Humanities and Social Sciences, BITS Pilani, \\ Hyderabad Campus, ORCID: oooo-0oo1-5034-0992.
}

Email: prasuna@hyderabad.bits-pilani.ac.in

\begin{abstract}
Yenugula Veeraswamaiyya's Kasi Yatra Charitra $(1838)$ is considered the first book written in the genre of travel writing in Telugu. A seminal work, it faithfully reflects and records the social, religious, political and economic life of people in those times, along with aspects of tradition and culture. A well-recognised scholar of his times, Veeraswamaiyya embarked on his journey to Kasi (Varanasi) in May 1830 from Chennapatnam (Chennai). He travelled for 15 months and 15 days and returned to Chennapatnam on September 3rd, 1831. He wrote about his experiences of travelling through Tirupati, Kadapa, Kurnool, Hyderabad, Nagpur, Jabalpur and Allahabad to reach Kasi. On his return journey, he travelled across Patna, Gaya, Calcutta, Puri, Ganjam, Simhachalam, Machilipatnam and Nellore, and finally reached Chennapatnam. His journey was unique because he took along with him, nearly 100 people consisting of his family, friends and servants. A travel of this scale needed meticulous planning. It could have been extremely challenging and adventurous to travel through unknown territories. These journeys had to be made by walking on foot and sometimes in a palanquin, carried by servants. According to Hindu belief, Kasi is the place where one attains moksha or liberation, and freedom from the cycle of death and rebirth. Hence, it is considered an important spiritual destination. This work is a storehouse of information and reflects the author's keen observation. This paper will explore the historical, cultural, social, economic and religious significance of Veeraswamaiyya's Kasi Yatra Charitra.
\end{abstract}

Keywords: Travel writing, Kasi yatra, pilgrimage, Telugu

\section{Introduction}

Yenugula Veeraswamaiyya's Kasi Yatra Charitra has a special place in the history of travel writing as it can be considered as the first book in Telugu in the genre. The first edition in Telugu was published in 1838 and was also translated into Tamil and Marathi. The second edition was published in 1869 and the third edition, in 1941. An organization called Janahitha, championed the cause of good literary values in Telugu, and initiated the huge task of identifying the best literary works in Telugu. It collaborated with the Telugu University in Hyderabad for re-printing these works and making them available for the general reader. It requested many prominent writers in Telugu to identify hundred best works that every Telugu reader must read. All of them named Kasi Yatra Charitra as a must-read book. In 1992, Telugu University published an abridged version of KasiYatra Charitra, edited by Muktevi Lakshmana Rao. In 1973, P. Sitapati and V. Purushottam edited and translated into English the original Telugu text compiled by K.S. Pillai and called it Enugula Veeraswamy's Journal.

(C) AesthetixMS 2020. This Open Access article is published under a Creative Commons Attribution Non-Commercial 4.o International License (http://creativecommons.org/licenses/by-nc/4.o/), which permits non-commercial re-use, distribution, and reproduction in any medium, provided the original work is properly cited. For citation use the DOI. For commercial re-use, please contact editor@rupkatha.com. 
The other prominent travel works in Telugu include Kola Seshachala Kavi's Nilagiri Yatra, a book about his experiences of travelling to Nilgiri hills along with his British masters. Noted scholar Chellapilla Venkata Sastry went on a pilgrimage to Kasi and wrote a book titled Kasi Yatra. Prof. Nayani Krishna Kumari travelled to Kashmir and wrote a travelogue titled Kashmira Deepakalika. Other prominent travel works in Telugu include Jonnalagadda Satyanarayana's Naa Maharashtra Yatra, K.V. Subbaiyya's Nava Bharatha Sandarsanam, Mallampalli Somasekhara Sarma's Naa Nelluru Mandala Yatra, and Mummaneni Lakshminarayana's Hampi Vihaarayatra.

\section{Veeraswamaiyya's Personality}

Yenugula Veeraswamaiyya started his journey to Kasi from Chennapatnam on $18^{\text {th }}$ May 1830 and returned to Chennapatnam on $3^{\text {rd }}$ September 1831 . He took with him over a hundred people consisting of family members including women, servants, friends, cooks and helpers. On the request of his friend Komaleswarapuram Srinivasa Pillay, he noted down all his travel experiences and observations in the form of letters. These were put together by his friend, and published as the book KasiYatra Charitra, in 1838. The Government ordered a re-print of the book in 1869.In fact, Veeraswamaiyya wanted to translate his work into English at the request of the British scholar C. P. Brown. But he passed away in 1836, without realizing this dream.

Veeraswamaiyya was a self-taught man. At the age of twelve, he was well-versed in English and joined the Madras Board of Trade as a volunteer. He was the most sought-after employee, as he was multi lingual and was well-versed in speaking and writing English, Tamil, Sanskrit and Telugu. At thirteen, he moved to Tirunaveli as an Interpreter in the District Collector's Office. Later he moved to Chennapatnam and joined the Madras Supreme Court as an Interpreter, which was considered a very prestigious job. This gave him an opportunity to work closely with the British. His command over the language, his knowledge about various aspects of Indian culture and tradition earned him much respect among the educated and intellectual circles of the British.

\section{The Aspects of Language}

Veeraswamaiyya used many English words in his work. He was a scholar in Telugu as well as in Sanskrit. But instead of writing in traditional Telugu or Sanskrit, he chose to write in verse. This book reflects the influence of colloquial Telugu spoken in some parts of Madras in those days. It also reflects the influence of English which was newly gaining popularity. Also, it showcases how English words were pronounced by Britishers as well as Indians who were familiar with the English language. Hence, from a linguistic point of view, this book is invaluable. He uses many English words like regiment, civil, court, collector, shop etc. He also uses Hindusthani words like savari, sarkar, musafir,shahar, elaka, naukar, fauz, jawan, zamindar, khiledaar, diwan, lashkar,khila, majboot, shaher, kothwal, thana, galli,dukaan,bazar, asoorkhana, inaam,raasta, seedha, hawaldar, bagicha, phirangi,fakir, ameer, haveli, etc.

\section{The Challenges of Travel}

During Veeraswamaiyya's time, there were no facilities for travel of this scale. He carried thousands of rupees with him, which had to be safeguarded throughout the travel. The safety of all the people who travelled with him, especially women, was also his responsibility. They travelled ten to twelve miles every day, crossing unknown dense forests, streams, rivers, and hilly 
areas. On their way they encountered wild animals and thugs, and the vagaries of weather. By the time they reached Kasi, the weather was very cold. Since they were used to warmer climates of Chennapatnam, they found it very difficult to bear the cold. Because of the large entourage, finding suitable accommodation and food supplies at small villages and towns was always a challenge. In spite of his best efforts, sometimes some essential items got washed away, when crossing streams.

Before Veeraswamaiyya started his journey, he obtained letters of recommendation from the Chief Justice and other officers in Chennapatnam. These letters reflected the importance and respect that he got from senior British officers. These letters helped him at various places in his journey to get royal treatment. In fact, based on these letters of recommendation, his contingent was given permission to carry arms for self-defence by the British Government in Calcutta. Normally, this permission was given only to the rulers.

In most places they could not find accommodation for such a big group. They had to stay in the premises of local temples, or put up their tents in nearby farms or open lands. Veeraswamaiyya hired people to carry the tents and fix them. He also carried many lengths of strong rope to draw water from wells. On the journey, most of his contingent suffered from indigestion, fever and wounds. As part of the preparation, he undertook a study of basic medicines, to be well-equipped with the necessary knowledge to help his troupe, in case of sickness. He carried suitable medicines to last the entire journey. As he carried large amounts of cash to spend on essentials, he hired special security guards with rifles to guard his money. He also bought two rifles in Cuddapah, in Andhra Pradesh.

Veeraswamaiyya had to go through customs checking at Juci Sarai, near Prayag, in spite of having valid travel documents and recommendation letters. When the senior officers in Prayag came to know of this incident, they immediately ordered the suspension of the concerned checking officers. This shows the respect Veeraswamaiyya commanded from the English officers outside his state as well. Since he was a compassionate man, he wrote to the senior officers to revoke the suspension of the employees who checked him. On reaching Prayag, he helped all the people who accompanied him, cooks and servants included, to fulfil all religious obligations, at his own expense.

\section{Social, Cultural, Spiritual, Religious, and EconomicAspects}

Veeraswamaiyya gave detailed descriptions of all the small villages and towns that he visited, on his way to Kasi. From Tirupati, he reached a place called Karakambadu, which had a post office and a government travel guest house. But since it was closer to the forest, there was fear of dacoits. The concerned collectors also tried their best to make it a safe place for travel, but could not succeed. It was impossible to cross the forest without local help. Veeraswamaiyya managed to convince twenty villagers, armed with rifles, to escort them to the next place. Closer to this place was another village called Balapalle which was one of the borders of Cuddapah district. From Balapalle to Cuddapah, the local Collector got the way paved, by cutting across the forest. He also set up police outposts on the way, for the security of the travellers. There was a Collector's office and a District Court in Cuddapah. There was also a military regiment stationed there. These details are important to understand all the administrative measures taken by the British even in relatively small, obscure villages.

Many small instances showcase Veeraswamaiyya's presence of mind. When he was travelling from a village called Atmakur, he realised that he had to make arrangements for 
essential items to be carried all the way to Srisailam town as nothing would be available on the way. There were four routes to go to Srisailam, out of which three were not suitable as the way was through a thick forest and there was fear of wild animals and tribals. The fourth one was also an uneven, steep road. Since it was a difficult route to travel, he assigned the job of making dolis or palanquins to the local carpenter. He paid two rupees for three dolis. He also hired eight people, to carry him in a doli, as well as to carry other essential items. He observed that the currency rate, when compared to the rupee in Chennapatnam was lesser by a quarter rupee in Atmakur.

The greatness and sanctity of Srisailam temple finds a mention in the Puranas also. Veeraswamaiyya was disappointed that there were no daily prayers or rituals followed at the temple. The water there was also not safe for drinking and often people suffered from fevers and other diseases. Though the Chenchu tribals stayed close to the temple in twenty huts, they too would leave the place in rainy season as the place was infested with flies. Veeraswamaiyya learnt that though the place was in ruins, with walls cracked up and wells dried up, there used to be a flourishing town around the temple at one time. The town had three hundred and sixty houses belonging to prostitutes. Many centuries earlier, the local ruler Anavemareddy spent a lot of money and got the entire temple gold-coated. The frescos on the walls of the temples which were in ruins, were still visible. Wild plants grew everywhere and snakes roamed freely.

On his way to Hyderabad, in a village called Pentapalli, the Nawab of Hyderabad maintained his army. Veeraswamaiyya made friends with the 'Khiledaar' ${ }^{i}$ and managed to get a few Jawans as security. He observed that the maps of some villages, made by the East India Company, were not accurate. The errors could have happened because of their spellings, registered as per the understanding of the British. This could be the reason for the distortion and confusion.

Veeraswamaiyya visited Begum Bazar and Shamshabad in Hyderabad. He stated that these places had many mosques and small streams, the water of which was used to cultivate mango groves and vegetables. He witnessed the Moharrum procession in Hyderabad. He observed that thousands of people of all religions and faiths came to witness the procession. He also visited Secunderabad, which had a British army regiment. Begum Bazar was a business area, where all essential household items and groceries were sold. Veeraswamaiyya also mentioned the famous Mecca Masjid and the fountain that Dewan Meer Alam built. There was also a market that sold clothes and utensils. Elephants were used as vehicles and moved freely on the streets, because of which many people carried arms as protection. The streets also had many fakirs begging for alms. The bridge across Musi River, built by the British was strong enough to take the weight of elephants also. Similarly, the Hussain Sagar Lake also had a bund constructed by the British, for the free passage of horse-drawn carts that was mostly used by the Britishers. He also visited Golconda Fort and was fascinated by the gardens there. It was common practice for rich people to chew betel leaf and smoke hookah. People ate rotis as well as rice. Fruits and vegetables were available in abundance, but were three times costlier compared to Chennapatnam. One rupee of Chennapatnam was valued at fifty paisa in Hyderabad. Whereever there was an exchange of currency, some amount was haggled and discounted.

Veeraswamaiyya believed that the places which were under the British rule were more secure and well-organized, when compared to places that were under private rulers. According to him, the poor suffered much more under private rulers as there was no accountability. People could not move freely and they lived in constant fear. He stayed in Hyderabad for twenty days before proceeding to Nagpur. But there was fear of dacoits and wild animals in dense forests on 
the way. He wanted someone, who was familiar with the way, to accompany him. So, he contacted the post office writer Master Luce, at Hyderabad British Residence. He requested him to arrange for postal runners (postmen familiar with the route) to accompany him in his journey, till the end of their geographical limits. From there, the responsibility would be handed over to the next postal runner. These postal runners were recognised as employees of the East India Company and were respected in their assigned villages. This arrangement turned out to be a great convenience. He gave one rupee to each of these postal runners, for their services.

Nagpur was under the control of the British for some time. They had helpful staff at every village who took care of visiting British officers as well as wealthy travellers. People mostly spoke Marathi, Hindi and Urdu. He stayed in Nagpur for a week to finalise arrangements for the rest of the journey. He bought two more big tents. He also took care of the repair work of his dolis. Nagpur had a big cantonment area. The place had beautiful English houses and shops that sold foreign goods for Britishers, run by the Parsis. The author observed that Nagpur cantonment did not have the grandeur of the cantonment in Hyderabad. The life style, traditions and attitude of people differed from those in South India. He made arrangements for six horses from Nagpur to carry tents and other essential items all the way to Kasi.

Veeraswamaiyya made an interesting observation about customs and traditions. Initially the women travelling with him followed all traditions of cooking and serving, even though it was challenging. They were upset when they could not find Brahmin houses to stay in some villages. They found it difficult to cook and eat in tents, when they travelled through forests and hills. For some time, they even avoided eating food that was cooked in the open. But over a period of time, they got used to everything. They ate food, irrespective of how and where it was cooked. They didn't care if someone was watching them while eating, a norm that was traditionally followed in Brahmin homes. Veeraswamaiyya felt that people and traditional norms change as per the changing needs of the situation.

Every state offered different experiences. In a place called Lalgunj, there was a lot of fear of dacoits. The British built a travel house there, with compound wall on all sides. They also appointed twenty-five police constables to safeguard the place. The gates would be locked at night and opened in the morning. Mirjapur was a big town with many markets. Various kinds of goods were transported to Calcutta, Delhi and other places by boats. At any time, there were at least two hundred such boats at the Ganga river ghat at Mirjapur.

Since he had the help of postal runners everywhere, there was no problem of losing his way or getting confused about the route. But as the weather got colder, people in his troupe fell sick more often. Sadly, one of his servants died at Mirjapur of cholera. From Mirjapur, he went to a pilgrim centre called Vindhya vasini, where there was a temple. The Goddess there was worshipped as Yoga Maya, Bhoga Maya and Kali. There were nearly 1000 priests in that area. Regular prayers were offered at the temple. The author also offered prayers, and as per the tradition there, the prasad-- the offering to the gods, consisting of pooris, doodhpeda and curd was distributed to everyone.

Veeraswamaiyya realised that performing religious practices with the help of the local pandas or priests was a very expensive affair, as they were very greedy. He managed to get a Telugu priest in Prayag to serve him and help him in performing all rituals. The local Customs Collector Sir Nippon, who came to know about his scholarship and knowledge, requested him to write a report on the flaws in the customs fee collection system. Veeraswamaiyya wrote the same and submitted it to Sir Nippon. He also had discussions about Hinduism and Christianity with him. The author observed that North Indian women were beautiful but they have no fancy for 
jewellery, unlike women in the South. The religious traditions followed there were also different from that of South. The language spoken in North India showed the influence of Hindi, Urdu and Sanskrit words.

From Prayag, Veeraswamaiyya proceeded to Kasi by boat. The journey normally took four days by road and six days by boat on the River Ganga. The author took the latter route so that his staff could get some rest. In Kasi, he stayed in a two-storied building at Kedar Ghat, on the banks of the River Ganga. The Gangaputra community in Kasi had the tradition of collecting money from pilgrims from generations. They fleeced the pilgrims and gave them a tough time. Veeraswamaiyya engaged a priest, whom he met in Nagpur, to travel with them and help them with all the rituals. This way he avoided any inconvenience to himself and his troupe. In Kasi, the five days starting from Ekadasi, the eleventh day of the lunar month, to Pournami, the day of the full moon, were called Pancha Ratnas and were considered very auspicious. Since Veeraswamaiyya was there at that time, he indulged in the holy bath in the River Ganga on the full moon day of Karthika Pournami which was believed to be very auspicious.

Veeraswamaiyya observed that the houses as well as the bathing ghats were very congested, even in those days. Land prices were very expensive. There were seven and eight storey buildings but the streets in front of them were very congested. Wolves wandered freely in Kasi. It was difficult to go from one ghat to the other on road. There were famous temples of Lord Visweshwara, Annapurna and Ganesh which he visited. He was surprised to find a big Masjid there. It was constructed by the earlier Mohammedan rulers who destroyed all the temples in Kasi. During the British period, these temples were repaired and revived. In Kasi, there were many British residences. There were also two customs collectors, one judge and one magistrate in Kasi. In a place called Sikhloor near Kasi, there were three battalions of army, headed by an English General. There was also a kothwal, a police officer and many areas had police stations. The narrow streets were called gallis and every galli had a gate which would be closed at 10.oopm every night. The constables patrolled at night. The East India Company established a school there and appointed ten teachers on a monthly salary of sixty rupees per head. The school had hundred students, who were given scholarship of three rupees each per month. All kinds of books were available in Kasi so the wealthy people ordered books from Kasi for their personal library.

The significance of Kasi has been detailed in the chapter called 'Kasi Khadam' in Skandapurana and also in other scriptures. According to the legend, Goddess Annapurna wowed that there would never be a shortage of food for people in Kasi. People also believed that Lord Shiva imparted the 'taraka mantra' to everyone who died in Kasi. This mantra ensured freedom from the cycle of death and re-birth, a reason why many people chose to spend their last days in Kasi. There were more than 1000 pilgrims at any time in Kasi. Veeraswamaiyya mentioned that there were three main issues with Kasi - 'raand', 'saand' and cheedi. Raand was the local word for widows. The place was full of young widows who pestered and begged the pilgrims for money. Saand meant bulls that moved freely in the streets of Kasi, attacking people and pulling out things from their hands. Cheedi meant steep steps. The place was full of them. Walking up and down these stairs was dangerous and also very tiring.

After spending ten days in Kasi, Veeraswamaiyya booked a big boat called bajra for himself and his family members and some small boats for other members of his troupe and travelled from Kasi to Patna. This was a ten-day travel. He explained all the problems he encountered during this boat journey. Sometimes water would seep into the boat. The servants fought among themselves and did not pay attention to his orders. He was also worried that he would be robbed of his money. On the way to Patna, there were many interesting places. One of 
these was Gajipur, where perfumes were made in the traditional way. Close by, there was a river called Karmanasini. People would not even put their feet into the river as the popular myth was that all your good deeds get washed away.

Patna was a big city. The place had a Collector, Judge, Magistrate, and a Commissioner who looked after revenue and criminal matters. There were many Muslims in the city. The houses were big and posh. The bazaars were very spacious. A little away from the city, the British built their residences with beautiful gardens. All kinds of fruits and dry fruits were available in Patna. The British already introduced the cultivation of potatoes, which were also freely available. In the market, there were many footwear and blanket shops as well as hookah shops. Like in Hyderabad, people carried arms freely, though there was a rule against that.

From Patna Veeraswamaiyya travelled to the pilgrim centre Gaya. The British built houses in a place called Sahebgunj and had made beautiful gardens there. There were many shops and bazaars there. Things were inexpensive. The place had a Magistrate, a district judge, a doctor, a tax collector to collect cess from pilgrims, and a District Collector. Foreign goods were also available. The place had many people from Maharashtra and Andhra residing there. There were near one thousand houses of local priests, who were quite wealthy.

The significance of Gaya, as detailed in Vayu Purana and Garuda Purana was popular there. In Gaya, Veeraswamaiyya and his troupe performed all religious obligations, like pindapradanam where a ceremony was observed to pay homage to the souls of the departed members of the family. Ten miles from Gaya, there was another place called Bouddha Gaya, which had a Buddhist temple there.

From Patna, he travelled to many places. At Bhagalpur, he noticed that the official language used in courts was Persian. The accounts were also written in Persian. On the way to Calcutta, there was a small hamlet called Srirampur consisting of Dutch people. There were also some areas under the control of people from Denmark and France.

Once he reached Calcutta, Veeraswamaiyya rented a house for fifty rupees a month, on the banks of river Ganga, near Chitpur. He also visited the Kali temple. There were Brahmin priests called 'pandas' offering prayers every day. On Fridays and Sundays, the temple was very crowded because animals were sacrificed there. He was surprised that Brahmins ate fish in Calcutta. Calcutta had many affluent people who moved there from nearby places, as they felt secure under the British. They built beautiful houses. The government offices also were very spacious and beautiful. There was an area called Garden Reach on the banks of the River Ganga. It had beautiful, big houses with spacious gardens. These houses belonged to Supreme Court judges and other affluent people. There were at least a thousand palanquins which had police license. Calcutta was a city of gardens. The Botanical Gardens was five miles long. Britishers established many schools in Calcutta. House rents and salaries of servants were also very high. The wealthy men imitated the western style of dressing. Business was flourishing. Export and import of goods from all countries was active. All foreign and domestic goods were available.

From Calcutta, on his way back, Veeraswamaiyya travelled across many small villages, towns and cities. Everywhere, he received royal treatment because of the recommendation letters that he carried. In Cuttack, Veeraswamaiyya visited the famous Jagannath temple. There was an entry ticket at the temple for outsiders. The temple was always crowded with people. Different varieties of prasad were offered to the deity seven times, every day. He also witnessed the famous Rathyatra of Lord Jagannath. There were nearly seven hundred houses belonging to the local pandas. 
On his return journey, Veeraswamaiyya travelled to Behrampur, Srikakulam, Vijayanagaram, Simhachalam, Anakapalli, Vishakhapatnam, Kakinada, Machilipatnam, Guntur, Nellore, Tiruvattur and many small villages. He completed his journey and reached Chennapatnam on September $3^{\text {rd }}, 1831$.

\section{Conclusion}

This work is considered the first in the genre of travel writing in Telugu. It is a unique, priceless contribution. It is invaluable for its accurate, meticulous account of every observation, experience, challenge and adventure. It is also an important reflection of all the positive contributions that the British made in India. It showcases the thirst for knowledge of Veeraswamaiyya and his ability for detailed planning. Veeraswamaiyya was an ordinary man, destined to do extraordinary things. He travelled for one and half years to far off unknown destinations, leading over a hundred people, assuming the roles of a leader, physician, care-taker and a provider. He believed that there would be many people in Chennapatnam who would consider Ganga water holy. So, he arranged for the transportation of forty-eight large vessels of the holy water to Chennapatnam, which he distributed generously.

This book also provided important, valuable details for travel enthusiasts of that time. The travel routes, places of stay, availability of essential facilities like food, water and accommodation, important places and temples to visit, details of forests, hills, streams, fields, villages, town, cities are all recorded. The historical and spiritual significance of the places of travel enroute to Kasi like - Tiruvallur, Tirupathi, Ahobilam, Srisailam, Prayaga, Kasi, Gaya, Jagannatham, Sri Kurmamu, DathaVaidyanathamu, Simhachalam, Kallepally, Srikakulam have been described. The significance of the rivers Ganga, Yamuna, Saraswathi, Godavari, Krishna, Sarayu, Shona Bhadra, Karma Nasini,Gandaki, Phalguni, SitaGundamu, Brahma Gundamu, Pinakini have been explained. Also, he described many interesting social, cultural and economic aspects pertaining to places like Hyderabad, Nagpur, Katakam, Calcutta, Rajamahendravaram, Patna, Ganjam, Vishakhapatnam, Vijayanagaram, Machilipatnam, Nellore, and Chennapatnam. Veeraswamaiyya also explained how one can travel from Kasi to other holy places like Brindavan, Haridwar, Badrinath, Kedarnath and Gangotri. Supriya Chaudhuri rightly points out another interesting fact when she tells us that Veeraswamiyya was an official interpreter for the Madras Supreme Court, favourably disposed towards the British, anxious to exploit his colonial connections and stay on good terms with local landowners while pursuing private religious ends. Still, his pilgrim journal includes acerbic comments

the rapacity of colonial commerce, especially at the shrine of Tirupati in southern India where he found the East India Company collecting a lakh of rupees as revenue.

Where Veeraswamy, part of the endless traffic of pilgrims crossing the Indian subcontinent and congregating at sacred sites, comes closest to modern travel writing is in his awareness of the human protagonist who must negotiate the secular boundaries of sacred journeys. His text conveys the 'blurring' of genres that the physical experience of travel produces in spatial, psychological, and aesthetic terms. (Chaudhuri, 2019, p. 161)

For all these reasons, KasiYatra Charitra occupies a unique place in the literary arena of Indian travel narratives and particularly in Telugu literature. 
40 | First Travel Narrative in Telugu: A Study of Yenugula Veeraswamaiyya's Kasi Yatra Charitra

\section{References}

Bhattacharji, S.(2015). Indian Travel Writing.The Routledge Companion to Travel Writing. New York: Routledge.

Chaudhuri, S. (2019). Indian Travel Narrative in The Cambridge History of Travel Writing. (Eds. Nandini Das and Tim Youngs). London: Cambridge. pp. 159-174.

Haridasu,M.(1992). Telugulo Yatra Caritralu. Karimnagar: Indu Pracuranalu.

Hanumantha Rao Muppalla.(1997). Samagra Andhradesa Charitra - Samskruthi. Rajahmundry: ABS Publications.

Hulme.P and Youngs.T. (Eds.)(2002) The Cambridge Companion to Travel Writing. Cambridge. Cambridge University Press.

Koti Reddy A.V. (2005). Andhra Desa Charitra - Samskruthi. Hyderabad: Krishna Reddy Publications.

Lakshmikantam, P. (1974). Andhra Sahitya Charitra. Hyderabad: Andhra Pradesh Sahitya Academy.

Lakshmiranjanam, K. (1951). Andhrula Charitra - Samskruthi. Kurnool: Balasaraswathi \& Co.

Muktevi Lakshmana Rao. (Ed)(1992).KasiyatraCharitra.(Ed). Hyderabad: Telugu University.

Nayar. P.K. (Ed).(2016). Indian Travel Writing. 1830-1947. New York: Routledge.

Pratapa Reddy Suravaram.(1992). Andhrula Samghika Charitra. Hyderabad: Andhra Sasaswatha Parishat.

Sitapati, P. and Purushottam, V. (Eds. \& Trans. )(1973). Enugula Veeraswamy's Journal. (Telugu original compiled K.S. Pillai). Hyderabad: Andhra Pradesh Government Oriental Manuscripts Library and Research Institute.

Shastri, DvaNa.(2007). Telugu Sahitya Charitra. Hyderabad: Pragati Publishers.

Venkatavadhani D.(1978). Sahitya Sopanamulu. Hyderabad: Andhra Saraswata Parishattu.

Veeraswamaiyya Y.(2014).Kasiyatra Charitra. NewDelhi: REEM Wisdom Pages LLP.

Youngs. T.(2013). The Cambridge Introduction to Travel Writing. Cambridge. Cambridge University Press. 